\title{
BIOLOGICAL FACTORS IN TISSUE TRANSPLANTATION
}

\author{
Roy Yorke Calne, M.S., F.R.C.S.
}

Lecturer in Surgery, St. Mary's Hospital, London, W.2

IN 1804 Baronio clearly demonstrated that experimental free skin autografts in a sheep would survive. The wide variety of free autografts now used in plastic surgery are ample testimony to his findings. Skin grafts exchanged between identical twins were first shown to survive by Bauer in 1927. Tissue transplants between members of highly inbred mouse strains are similarly accepted. A kidney that is removed and transplanted into the same individual, or his identical twin, will function almost as efficiently as before it was disturbed and can alone maintain the life of the organism for a period of years (Murray, Merrill and Harrison, 1958). Thus where genetic differences between graft and recipient can be excluded, technical considerations are the only important factors that determine the survival of transplanted tissue and although technical difficulties might be considerable, they are for the most part understood.

In the present century in almost every branch of surgery, technical progress has resulted in successful exploitation of tissue transplantation within the same individual, either free, or with a partially intact blood supply. However, although these developments have been of great value, they have distinct limitations as to the source of the donor tissue. Thus if vital organs such as kidneys are irreversibly diseased or if an excessive amount of skin is burnt, the patient cannot supply the deficient tissue and surgery has little to offer him, unless he is fortunate enough to possess an identical twin.

Jensen in 1903 showed that certain spontaneous tumours in mice could be transplanted and would continue to grow within some strains of inbred mice, but if the tumours were transplanted to individuals of another strain they would grow for a period and then be rejected. After rejection, if the same tumour source was transplanted to the same recipient a second time, it would not now survive even temporarily. These observations were the first demonstration of immunity to homologous tissue, although originally they were thought to represent properties of neoplastic as opposed to normal tissue.

In 1911, Lexer, having made a study of skin grafts, stated categorically that skin homograftsoo never take permanently. Holman in 1924 showed that a second skin homograft from the same donor to the same recipient was more rapidly rejected than the first. Confirmation and amplification of $\mathrm{o}_{0}$ these findings were the first subject of the classical studies of Medawar and his associates (Gibson $\overrightarrow{0}$ and Medawar, 1943; Medawar, 1944, 1945; Billingham, Brent, Medawar and Sparrow, 1954)응

The observation of these basic facts of homotransplantation, that were generally applicable goce all vertebrate species studied, far from solving amy of the problems, merely defined the field for vestigation as follows:

1. What genetic factors are concerned in the rejection of homologous tissue?

2. How is grafted tissue destroyed ?

3. What is the mechanism of the heightened specific immunity that follows rejection of $\overline{3}$ the first graft ?

\section{Genetic Factors}

It was apparent from the observations that identical twins and certain inbred mice would not reject tissue grafts from their appropriate partners, that tissue antigenicity was dependent on genetion differences between donor and host. This has弓 been clarified by the work of Snell (1953a) and Gorer (1956). In mice, the genetic locus mos? studied, the $\mathrm{H}_{2}$ locus, may contain $\mathrm{I} 2$ alleles, and there may be 15 loci where tissue antigenic properties can be referred (Snell, 1953b).

Within an unrelated population, skin homo+N grafts may be rejected in as little as five days N whilst at the other extreme in certain inbre of strains of mice, Eichwald, Silmser and Wheeler (1957) have shown that possession of a single weate factor by the male, presumably on the $\mathrm{Y}$ chros mosome, will cause rejection of skin grafts from male into female after a period extending in somes cases up to roo days. The female, not having this 
factor, can donate skin to another female $\mathrm{cr}$ a male that will not be rejected.

The histocompatibility genes governing transplantation rejection have independent actions, so that successful survival of a graft requires that the recipient possesses all the dominant genes of the donor. Thus $F_{I}$ hybrids of the crossing of two inbred parental strains will accept grafts from either parental strain, although either parental strain will reject grafts from the $F_{I}$ hybrid.

The relationship between red blood cell agglutinogens and histocompatibility factors varies in different species; thus in the mouse Gorer (1937, 1938) showed that tumour homografts produced serum isoantibodies, which agglutinated donor red blood cells. Similar isoantibodies were found following skin homografts (Amos, Gorer, Mikulska, Billingham and Sparrow, 1954). These workers also demonstrated that red blood cell antigens in mice are controlled by the $\mathrm{H}_{2}$ locus, which has, in addition, important histocompatibility functions (Amos, Gorer and Mikulska, I955). However, an identity of the potent red blood cell factors between donor and recipient in man does not appear to influence favourably the survival of homografts. Merrill, Murray, Harrison, Friedman, Dealy and Dammin (1960) have observed rejection of skin between non-identical twins, who nevertheless shared 23 blood group antigenic categories.

These observations indicate that the red blood cell and histocompatibility factors may move together in a genetic sense, but there are important demonstrable antigenic differences between them.

Thus rejection sooner or later is the rule, with tissues transplanted between unrelated individuals, and, although sharing of some histocompatibility factors in man may be relatively common (Friedman, Retan, Marshall, Henry and Merrill, I96r), the likelihood of a chance identity of all the histocompatibility genes in two individuals taken at random from the general human population must be exceedingly small. At present there are not sufficient data to assess this probability numerically and there is no method of typing, short of grafting, which a priori would appear to be an unrewarding task.

\section{The Mechanism of Homograft Rejection}

The transfusion of homologous red blood cells from a group A human donor to a group B recipient results in a rapid destruction of the donor cells due to naturally occurring circulating anti-A agglutinins. However, a skin graft from a group A donor to a group B recipient behaves initially like an autograft in that, if technique is satisfactory, many cells retain their viability and vascularization is established. From about the fifth day onward, however, changes occur that lead progressively to destruction of the graft. The salient features of these changes are a mononuclear cellular infiltration of the graft and eventual cessation of blood flow through the graft with resulting necrosis. Skin grafts between human beings of any other blood groups behave in a similar manner and it can, therefore, be forcefully argued that with homologous first-set skin grafts there is no preformed tissue-destroying antibody in the circulation and an essential difference exists between red blood cell and skin destruction.

Medawar (1944, 1945) clearly demonstrated the immunological character of the rejection of skin homografts in an outbred population of rabbits. The term 'immunological' requires an antigenic afferent stimulating factor, a recognition and reacting centre and an effector mechanism.

\section{The Antigen}

The basic system of study of the antigen has been the second-set phenomenon. It has been found that nucleated living cells from every tissue so far investigated possess the ability to sensitize a recipient so that subsequent exposure to tissue from the same donor results in an accelerated rejection of the second-set graft. However, nonnucleated red blood cells do not possess this property (Billingham, Brent and Medawar, $1956 \mathrm{~b}$ ).

Attempts to isolate and identify the antigen have not so far been conclusive. Medawar (1957) found that antigenic activity was lost when the extracts were treated with deoxyribonuclease, but the extracts were resistant to ribonuclease. Haskova and Hrubesova (1958) found that deoxyribonucleoprotein was not the antigen; they had evidence suggesting that antigenic activity was present in a mucopolysaccharide cellular extract. This was confirmed by Medawar (1958). Mann, Corson and Dammin (I960) have found a particulate cellular fraction, possibly a lipoprotein, that will cause transplantation immunity. Similar antigenic preparations have been studied by other workers (Davies, 1962; Herzenberg and Herzenberg, 196I ; Castermans and Lejeune, I962) and it has been suggested by Herzenberg that the antigenic determinants may reside in cell membrane.

\section{The Recognition and Reacting Centre}

Medawar (1956) has conclusively demonstrated that nodal lymphoid cells are able to recognize and react against homologous tissue. This critical experiment will be discussed with the phenomenon of immunological tolerance. Only lymphoid cells have been shown to be immunologically competent and it is not known if all or only a limited proportion of lymphoid cells can react against a given antigen. The potential immunological ability of 
lymphoid cells has been fully discussed by Burnet (1959), who favours the hypothesis that stem cells of the lymphoid series possess a limited potential of antibody reactivity and when stimulated by an antigen against which it can react such a cell gives rise by mitosis to a clone of progeny specifically active against the antigen. The alternative to this clonal selection theory requires that the antigen imparts to a pluripotent cell specific instructions which determire antibody production.

It has long been suspected that cells of the plasma cell series can produce antibody (Fagraeus, 1948). This has now been confirmed by Nossal (1959) who has shown that a single plasma cell can synthesize antibody.

\section{The Effector Mechanism}

First-set tissue homografts become infiltrated with lymphoid cells during rejection. The suggestion that these cells were directly concerned in the rejection process was first made by Murphy in 1926. Strong evidence supporting this concept came from the studies of Weaver, Algire and Prehn (1955). They showed that first-set or second-set homografts, enclosed within porous membranes, were not destroyed if the pores were smaller than lymphoid cells; however, if the pores were larger than lymphoid cells, the grafts were destroyed and a lymphoid cellular infiltrate occurred.

Circulating antibodies have been observed following the application of homografts (Gorer, 1937; Amos and others, 1954). Some of these antibodies agglutinate red blood cells and are probably the result of immunization with bloodgroup antigens which are widely distributed in the tissues (Coombs, Bedford and Rouillard, 1956). It had been suggested (Medawar, I957) that there was a distinct difference between antigens that produce circulating isohæmagglutinins, ' $\mathrm{H}$ ' antigens, and antigens that give rise to transplantation immunity, the ' $\mathrm{T}$ ' antigens. However, recently Brent, Medawar and Ruszkiewicz (1961) have found that a cell-free antigen extract will produce both humoral antibodies and sensitize against skin grafts and they now feel unable to uphold a distinction between ' $\mathrm{H}$ ' and ' $\mathrm{T}$ ' antigens. Skin transplantation immunity can be transferred by cells, but attempts to transfer this immunity with serum, even when this has a high isoagglutinin titre, are usually unsuccessful. Further, a high titre of isoagglutinins may be associated with a diminished homograft reactivity rather than immunity (Kaliss, I957).

However, Gorer (1955) and Gorer and O'Gorman (1956) have demonstrated cytotoxic antibodies in mice for both skin and tumour homografts, and in rabbits following skin grafting,
Teresaki, Bold, Cannon and Longmire ( $196 \not{\text { \ै }}$ have found antibodies toxic to donor lymph nod cells. Although, as has been stated, mos attempts to transfer transplantation immunity with serum from immunised animals have been un $\overrightarrow{\vec{F}}$ successful, Stetson and Demopoulos (1958) dig produce such a transference in rabbits immunizeg with spleen cells, and Steinmuller (1962) was able to transfer skin graft immunity passively, wit isoimmune serum, between rats of widely un related strains.

Thus, a clear picture of the significance $\$ \vec{\Phi}$ circulating antibodies in the homograft reaction cannot at present be obtained. Homografts carfw apparently, be destroyed in the absence of cire culating antibodies; fotal sheep can reject sking homografts before their blood contains gamma globulins (Schinkell and Ferguson, 1953). How ever, it is certainly not proven that circulating antibodies never play a part in the rejection of homografts. Batchelor, Boyse and Gorer (1960\%0 have demonstrated a synergic action betwees isoantibody and immune cells in tumour homo $=$ graft rejection. It is quite possible that suclo synergism may be an important aspect of trans 0 ? plantation immunity. Amos and Wakefield (1959 have pointed out that interpretation of the diffusion chamber experiments, referred to above, nefs require modification. In their experiments with milipore chambers, a low complement level ins: the chambers prevented antibody from lysing the cells, thus, when more complement was added the cells were destroyed without host lymphoid cellæ passing the membrane.

It would, therefore, appear that at present there is much experimental evidence in favour of both cells and circulating antibody having important roles in the effector mechanism of homograft. immunity. They can apparently destroy grafted tissue independently of each other, but they can. also work together in the elimination of homologous tissue.

\section{Organ Transplants}

Most investigations of the transplantation of intact organs, in which immediate vascular con $\rightarrow$ tinuity is re-established by anastomosis, have been made on the kidney. However, Lower s Stofer and Shumway (196r) have developed a very" satisfactory technique for heart transplantation in the dog and one of their animals survived for morew that a year with a completely denervated auto- transplanted heart. Autotransplants of lung alsoo function satisfactorily for prolonged periods (Neptune, Weller and Bailey, r 953). Homologous ${ }^{\text {? }}$ transplants of these organs have been no more? successful than homologous kidney transplants? and the rejection process of the heart is certainly 
very similar to that in the kidney, there being a marked perivascular lymphoid cellular infiltrate. Although there are fewer data for homologous spleen and liver transplants, there seems to be little doubt that these behave in a similar manner (Moore, Wheeler, Demissianos, Smith, Balakura, Abel, Greenberg and Dammin, 1960).

Observations of experimental renal homotransplants have been of a similar nature to those outlined for other tissues; there have, however, been differences in interpretation. Dempster (1953) and Simonsen, Buemann, Gammiltoft, Jensen and Jorgensen (1953) performed careful studies of first-set and second-set renal homotransplants in dogs and confirmed that first-set homografts usually ceased to function after five to eight days. They noted a pyroninophilic cellular infiltration of the renal cortex during the process of rejection and demonstrated that a second kidney from the same donor was rejected more rapidly than the first kidney, and often the rejection of the second-set kidney was not accompanied by a cellular infiltration. Both these workers thought that the lymphoid cells came from the kidney and represented a reaction of the kidney against the recipient, the first proposals for a graft-versus-host reaction. However, recent studies in which the lymphoid cells were labelled with tritiated thymidine strongly suggest that the infiltrating cells are of recipient origin (Porter and Calne, 1960).

\section{Prevention of Rejection of Homologous Tissue}

In view of the obvious clinical applications, prolongation of homograft survival has been the subject of much study. Assuming the previously outlined mechanism of biological rejection to be correct, the problem could be approached theoretically as follows:

I. Render the graft non-antigenic.

2. Prevent the antigenic material reaching the lymphoid system.

3. Prevent recognition of the antigenic material by the lymphoid system.

4. Prevent the central mechanism reacting against the antigenic material.

5. Prevent lymphoid cells reaching the graft.

These will now be considered.

\section{Render the Graft Non-antigenic}

Tissue antigenicity is genetically determined and the antigenic properties apparently reside in a complex material that is present in all nucleated cells. It is, therefore, not surprising that attempts to impair antigenicity, whilst maintaining cell viability, have been wholly unsuccessful. Thus, if continued life of the graft is desired, such an approach cannot be made. If the antigenic factors had been isolated and their chemical nature was understood, the problems would be clearer, but at present further speculation would not be profitable.

There is considerable literature, reviewed by May (1959), testifying that fœtal tissues are often not antigenic. In conflict with this view was the active rejection of fotal tissue 50 days before birth by fœtal sheep, observed by Schinkel and Ferguson (1953), and similar findings of rejection of mouse fœtal tissue by adult mice (Billingham, Brent and Medawar, 1956a).

Alternative explanations for the reported successes depend on the site and the nature of the transplanted fœtal tissues, rather than these tissues being non-antigenic. Thus many of the successful fœtal grafts were transplanted into the brain, from where the histocompatible antigens are unable to reach the lymphoid centres, or the anterior chamber of the eye, to which place the effector mechanism has no access. Many other successful fœtal grafts were of endocrine tissue, which is peculiar in being less liable to homograft rejection than most other tissues even when from an adult source. These factors will be considered more fully later.

\section{Prevent the Antigenic Material Reaching the Lymphoid System}

Homologous tissue grafted into the brain may survive (Murphy, 1926). However, if the recipient has been first immunized by, say, an orthotopic skin graft, then a subsequent second-set graft in the brain will be destroyed (Medawar, I948), indicating that a graft in the brain is not safe from a homograft reaction once elicited centrally, but by itself it cannot produce the reaction. It is suggested that the lack of lymphatic drainage of the brain is the reason for the especial dispensation accorded to homografts in this situation. The brain may well be an example of a site from which antigsnic material cannot reach the lymphoid system.

Casey, Meyers and Drysdale (1948) showed that the growth of tumour homografts could be 'enhanced' by pretreatment of the recipient animals with derivatives of dead tumour cells. Mitchison and Dube (r955) showed that this enhancement could be abolished by transfer of lymphoid cells from previously immunized isologous animals. Enhancement can be passively transferred by serum, which is found to contain high hæmagglutinin titres. Kaliss (1958) defines enhancement as ' the successful establishment of a tumour homograft and its progressive growth (usually to death of the host) as a consequence of the tumour's contact with specific antiserum in the host'.

Billingham, Brent and Medawar (1956b) produced partial enhancement of skin graft survival in mice; however, this enhancement never permitted skin homografts to survive more than 
double the expected period. Prior immunization with living cells prevented subsequent production of enhancement with non-living tissue preparations. These workers suggested that hæmagglutinins may be able to inactivate transplantation antigens, preventing them from reaching the immunological reacting centre; thus the phenomenon of enhancement would be an example of afferent inhibition of transplantation immunity. Snell, Winn, Stimpfling and Parker (1960) have recently produced convincing evidence that antiserum alters the response of the host by blocking development of the cellular type of immunity, and further studies by Brent and Medawar (I96I) suggest that enhancing antibodies may act centrally. It is of interest that in the experiments of Batchelor, Boyse and Gorer (1960) the serum antibody, which acted synergically with sensitized cells in destroying tumour homografts, when used without cells, produced enhanced tumour growth.

Billingham, Krohn and Medawar (195 Ia, 195 Ib) found that treatment of the recipient animals with cortisone prolonged survival of skin homografts in rabbits three to four times the normal survival period; they thought that it acted by retarding release of antigen. Cortisone treated rabbits certainly vascularize skin homografts slowly. However, the central inhibitory action of the corticosteroids on the reticuloendothelial system may well be another contributory factor to the prolonged survival of these grafts.

\section{Prevent Recognition of the Antigenic Material by} the Lymphoid System

To survive in an environment where exposure to virulent micro-organisms is commonplace, the possession of a lymphoid system that can recognize and specifically react against exogenous material is an obvious advantage. There must, however, be a safeguarding mechanism preventing reaction against the organism's own body constituents, but there is no apparent biological reason why the recognition system should be selective in its reaction against exogenous material, attending to the destruction of harmful bacterial antigens, yet accepting homografts, since the ability to accept homografts has never been of survival advantage in evolutionary selection.

In 1945 Owen observed that most dizygotic cattle twins are red blood cell chimeras, each twin having its own and its partner's red blood cell antigens. Such twins are synchorial and, therefore, exchange fœtal blood, moreover a female dizygotic twin partnered to a male is usually a sterile freemartin. It was suggested by Lillie (19I6) that this sterility is due to male hormones from the partner circulating in the female embryo. Red blood cell chimerism has also been observed in sheep (Stormont, Weir and Lane, 1953) and i⿱⺈ man (Dunsford, Bowley, Hutchison, Thompso产 Sanger and Race, 1953).

Anderson, Billingham, Lampkin and Medawai (195I) attempted to distinguish monozygotic frot dizygotic cattle twins by skin grafting. They had no success as they found that dizygotic catte twins accepted skin from their respective partners This finding led to a series of experiments the revealed a new approach to problems of tissue trans plantation and amply fulfilled the prophesies of Burnett and Fenner (I949), who had suggested that in embryonic life the reticuloendotheliat system must learn to distinguish ' self' from ' none self' constituents and that native factors would have a protective 'self marker'. If the embryo presented with foreign material before it his developed the ability to make the distinction, is will accept this material as if it were its own an subsequently will not be able to react against if The naturally produced tolerance to dizygotic twin tissue is highly specific and applies only to the twin in question; the ability to react against homografts from siblings other than the twio partner is retained.

Experimental production of immunologica tolerance fully confirmed this interpretation of $d$ h phenomenon in dizygotic calf twins. Billing and others (1954) produced lasting and speçfic immunological tolerance in mice by injecting embryos of one highly inbred strain with livin cells of another inbred strain and subsequent challenging the injected animals after birth wit skin grafts from the original donor strain. Ths homologous tissue often survived permanentl $\overrightarrow{\vec{Q}}$ If the initial injection was delayed until the day of birth, tolerance could still be produced (Billingham and Brent, 1957) but injection between 24 and 72 hours after birth, the so-called 'neutral' period produced no effect. After this period injection. merely produced immunity with an aggravate second-set rejection. An initial injection of spleen or kidney cells produced tolerance to sking indicating a tolerance to the organism in questiog with no evidence of tissue specificity.

Brent and Gowland (196r) have investigated the relationship of cell dose and age of host in the in duction of tolerance. They found that increasing the cell dose did extend the period during whicho tolerance could be elicited, but a limit was reaches beyond which further antigen dose did not result in tolerance.

The greater the genetic differences between donor and recipient, the more difficult it is to obtain tolerance, nevertheless, prolonged embryo nic parabiosis has resulted in the production of tolerance between two distinct species of duct (Hasek, Hort and Chutna, 1962). 
Tolerance is sometimes only partial, the second challenging grafts being rejected after a delay. In rats the tolerance-responsive period may extend up to two weeks (Woodruff and Simpson, 1955). However, embryonic sheep 50 days before birth, if skin grafted, instead of becoming tolerant to the skin, are able to reject it in a similar manner to adult sheep (Schinkel and Ferguson, 1953).

Tolerance can be broken by the process of ' adoptive immunization ', first used by Mitchison (1953) to demonstrate that cellular immunity to tumour homografts resides in lymph node cells. Billingham, Brent and Medawar (1953; 1956b) showed that mice made tolerant to skin grafts from another strain, if injected with lymph nodes from a non-tolerant mouse of the same strain as the skin graft recipients, lost their tolerance and rejected the skin graft. This occurred most quickiy if regional lymph nodes draining the grafted area of a specifically sensitized animal were used, but rejection also occurred with lymphoid cells from a non-sensitized animal. An elegant elaboration of this experiment using adrenal grafts instead of skin in adrenalectomized mice, resulted in an 'immunological adrenalectomy' after adoption of lymphoid cells from a non-tolerant isologous source (Medawar and Russell, 1958).

These experiments produced added evidence that tolerance, like immunity, is genotype specific but not tissue specific and they also clearly showed that lymphoid cells can assume the central role of recognition and effector mechanism in homograft rejection. It is also apparent from these experiments that tolerated grafts retain their antigenicity; it is the recipient who has become adapted to the graft and not vice versa. It would seem likely that the factors liberated from a homograft are also liberated by normal ungrafted tissue and that antigenicity is only demonstrable when immunologically competent cells recognise such factors as foreign.

Immunological tolerance can also be produced by a wide variety of antigens. There is evidence from observations with soluble antigens that continued presence of the antigen is necessary for a continuance of the state of tolerance (Smith and Bridges, I 958).

Felton (1949) showed that very large doses of pneumococcal polysaccharide prevented adult mice from acting against pneumococci. This 'immunological paralysis' was specific for the antigen in question. It was long-lasting and directly related to the antigenic dose. Recent work by Dresser (1960) suggests that this phenomenon may be related to immunological tolerance.

The mechanism of tolerance production is not known. Medawar (1960) has reviewed a variety of hypotheses and concludes that the choice at present lies between the following:-

I. Antibody-forming cells are a heterogeneous population. Individual cells have a predetermined ability to act against a given antigen. When exposed to this antigen, the mature cells proliferate and form specific antibody, whilst the immature cells are destroyed. In the embryo there are few, if any, mature cells and the specific destruction of the immature cells results in lasting tolerance to the antigen in question. This would be in accord with Burnet's (1959) clonal selection theory of acquired immunity.

2. Exposure to antigen results in stem cells becoming tolerant and mature cells becoming immune. In the embryo there are few, if any, immunologically mature cells, therefore tolerance is produced. In the adult the sensitization of mature cells masks any tolerance produced simultaneously in stem cells. This 'stem-cell' theory referred to by Brent and Gowland (I96I) would maintain that tolerance is a phenomenon quite distinct from immune paralysis, the latter being produced by a different mechanism, possibly destruction or inhibition of mature cells by huge doses of antigen. Certainly the dictum 'one cell, one antibody', which was pertinent to the clonal selection theory, can no longer be upheld, since Attardi, Cohn, Horibata and Lennox (1959) and Makela and Nossal (I96r) have demonstrated that one cell can produce at the same time two distinct antibodies.

\section{Prevent the Central Mechanism Reacting Against the Antigenic Material}

Miller (196I) and Good (196I) have shown that mice thymectomized within the first 24 hours of birth develop a severely impaired immune system. The lymph follicles in nodes and spleen become atrophic, with few plasma cells even after antigenic stimulation. These animals are very susceptible to infection and their ability to reject homologous and even heterologous skin grafts is depressed; indeed, some skin grafts have persisted several months longer than the controls. The most likely explanation of these findings at present is that the thymus at a very early stage in life produces the originators of immunologically competent cells, or controls their differentiation.

If the immunologically competent cells are destroyed or their function inhibited, then homografts would be expected to survive. Jacobsen (1952) and Lorenz, Congdon and Uphoff (1952) found that the lives of 'lethally ' irradiated animals could be saved by injection of hæmatopoietic tissue from another animal. The following year Barnes and Loutit (1953) showed that transplantation of living hæmatopoietic cells was the critical factor 
in this salvage and that the injected cells colonized the marrow cavities of the recipient that had been depleted by irradiation. The irradiated animals would also accept skin grafts from the donors of the hæmatopoietic tissue.

This phenomenon differs markedly from immunological tolerance in lacking specificity. The reticuloendothelial system as a whole is destroyed and any homologous, and in some cases even heterologous, hæmatopoietic tissue will be accepted as a life-saving graft. The marrow graft takes over the immunological responsibilities of the irradiated host. However, such an animal is very susceptible to infection and Piomelli, Behrendt, O'Connor and Murray (196I) have shown that irradiated rabbits, with marrow grafts from unrelated donors, will accept skin grafts from indifferent donors quite distinct from the marrow donors, provided these skin grafts are applied shortly after irradiation. These workers also found that the survival of skin homografts was prolonged in animals subjected to supralethal irradiation and given stored autologous marrow. Thus during the period immediately following irradiation the grafted hæmatopoietic tissue is not able to maintain an efficient immunological defence.

\section{Prevent Lymphoid Cells Reaching the Graft}

Corneal homografts are known to survive provided that they are not vascularized. It has been convincingly demonstrated by Billingham and Boswell (I953) that this property is due to the site being inaccessible to the effector mechanism. Thus homologous cornea grafted to the subdermis is rejected, whilst homologous skin grafted to the cornea survives even in a specifically immunized animal. The same factors govern survival of homografts in the anterior chamber of the eye. Cartilage homografts will often survive and lack of access of the effector mechanism to the walled-off cells is probably again the explanation (Gibson, Curran and Davis, 1957). The experiments with homografts enclosed in porous membranes that will not allow passage of lymphoid cells to the graft have already been mentioned.

\section{Reaction of Graft Against Host}

Dempster (1953) first suggested that a homograft containing immunologically competent cells might react against the recipient. If adult lymphoid cells are injected into unrelated animals to produce immunological tolerance, or to repopulate the marrow of irradiated animals, in either case the recipients are unable to react against the injected cells and the stage is set for a graft versus host reaction. This is probably the explanation of ' runt' disease in tolerant mice (Billingham and Brent, 1959) and 'homologous' or 'secondary' disease in irradiated animals (Trentin, 1956). Mice with runt disease fail to thrive and are susceptible to infection. A similar disease can affect tolerant chickens: such animals often develop gross spleno: megaly (Simonsen, 1957). A proportion of irradi(s) ated and marrow-grafted animals suffer from diarrhœa and wasting (Graber, Courcon, Merriltㅗㅗ. Ilberg and Loutit, 1958); there may be, isp addition, a hæmolytic process (Porter, I960a Piomelli and Brooke, r960).

The observations that fotal lymphoid tissue which can, presumably, become tolerant to hos? antigens, does not produce these syndromes is evidence in favour of the above interpretation of these diseases (Barnes, Ilbery and Loutit, 1958ם Uphoff, 1958; Porter, 1959).

Any attempts to utilize immunological tolerancis or irradiation and marrow grafting for clinical purposes would raise the theoretical possibility of a graft versus host reaction, unless only immunocr logically incompetent or fœtal cells were used a grafts.

Whenever immunologically competent cells are injected into an animal there is the possibility thas these cells may survive and initiate or contribute to immune reactions. Howard and Woodrup (I96I) found that a graft versus host reactign $\overrightarrow{-}$ produced by intravenous injection of pare strain spleen cells in $F_{1}$ hybrid mice, resulted i depressed ability of the animals to react againso bacterial antigen and to reject skin grafts. Kolles and Doak (1959) salvaged irradiated mice wit/ homologous marrow and challenged them wit skin isografts and homografts from the same straip as the marrow. As would be expected, the homo $\overrightarrow{0}$ grafts persisted, but the isografts were rejectedB This was a dramatic expression of graft versuz্ host reaction and, in addition, suggested an in? creased vulnerability of grafts during the healing in phase, since the animals' own skin, of at. identical antigenic constitution, was able to with stand the graft versus host reaction.

Nakic (1962) believes that the activity of injecte $\Phi$ immunologically competent cells is the centrat mechanism of the induction of tolerance. Accordo ing to his theory, these cells compete with and, to 7 varying extent, replace the host's own lymphoie. cells. In sympathy with this hypothesis, parabiosis experiments of Jensen and Simonsen (1962) suggest that a graft versus host reaction facilitate the induction of tolerance between parabiotie partners.

The concept of tissue transplantation immunityo which has been discussed, leaves large gaps of ignorance of basic principles. There is little positive evidence on the nature of the rejection of second-set grafts. When second-set homograft are applied, cellular infiltration is often intense iक्ष 
the graft bed of the host, the homologous tissue itself having little infiltrate. The passive transfer of immunity to skin homografts with serum from immunized animals by Stetson and Demopoulos (1958) is evidence in favour of circulating antibody playing a part in homograft rejection, and this is supported by the vascular lesions in some secondset renal homografts, where no infiltrating cells can be found. Dempster (1953) and Simonsen and others (1953) independently described changes in some second-set kidney homografts of massive vascular disruption in the renal parenchyma, with no cellular infiltration. However, antibodies of a conventional type have not been consistently demonstrated.

If the thesis of cellular-mediated rejection of first-set homografts is true, there is as yet no knowledge as to how the activated lymphoid cells become attracted to the graft and by what mechanism they damage it. The bare facts that will stand up to criticism are that transplanted tissues liberate material, which, if homologous, is recognized as foreign by certain lymphoid cells, which infiltrate the graft and are associated with its destruction. A state of immunity of varying degree then exists for a variable length of time, during which period further homologous tissue transplanted from the same source will be destroyed more quickly than the first graft, sometimes with little or no cellular infiltration.

In general, there is no evidence of tissue specificity to transplantation immunity and tolerance; however, anomalies do occur. Thus some endocrine gland homografts will survive much longer than skin. Lanman (1962) has demonstrated that the placenta is insensitive to homograft immunity. There are at present no satisfactory explanations for these findings.

\section{Prevention of Rejection of Experimental Renal Homografts}

Until more is known of the basic factors concerned in rejection of homologous tissue attempts at preventing this process will remain empirical. Most of the experimental approaches to prevent the rejection of homografts are not at present applicable to clinical renal transplantation.

The only methods by which the functional survival of experimental renal homografts in immunologically mature animals have been prolonged are total body irradiation and drug treatment of the recipient animals.

\section{Total Body Irradiation}

Dempster (1953) and Baker and Gordon (1955) found that total body irradiation in a dose of 200 to $250 \mathrm{r}$ did not produce prolongation of function of renal homografts in dogs, whether or not the donor was irradiated in addition to the recipient. Mannick, Lochte, Ashley, Thomas and Ferrebee (1959) irradiated a dog with $1,300 \mathrm{r}$ total body dose, which is in the supralethal range. They gave the animal an homologous marrow graft and then transplanted a kidney from the dog that had donated the marrow. The dog survived 49 days after the kidney was transplanted; the transplanted kidney had alone supported the life of the dog during its last 37 days. The animal died from pneumonia and the kidney showed no microscopical abnormality.

Hume, Jackson, Zukoski, Lee, Kauffman and Egdahl ( 1960 ) found that 600 to $I, 000 \mathrm{r}$ total body irradiation to the recipient did not prevent a typical homograft reaction when a kidney was subsequently transplanted. However, 1,200 to $1,500 \mathrm{r}$ total body irradiation to the recipients prevented histological evidence of a homograft reaction for the 4 to 13 days that the animals survived the irradiation.

Total body supralethal irradiation with a successful permanent homologous marrow graft has not yet been achieved in man. Most cases of clinical supralethal irradiation have been patients with leukæmia; temporarily successful marrow grafts have been rejected at the same time that the leukæmia recurred (Mathè, Thomas and Ferrebee, 1959; Thomas, Lochte, Cannon, Sahler and Ferrebee, 1959). Supralethal irradiation of dogs had a high mortality even when adequate marrow grafts were used (Ferrebee, Lochte, Jaretski, Sahler and Thomas, 1958). The animals are initially immunological cripples, and are excessively liable to infection. The irradiation usually causes gastrointestinal damage, which can be lethal. Further, there is a danger of a graft versus host reaction unless fœtal hæmatopoietic tissue is used, which is not immunologically competent. Thus it is quite clear that in the dog total body irradiation of recipient animals, with up to $I, 000 \mathrm{r}$, does not prevent rapid rejection of a renal transplant, although in the absence of a protective marrow graft, $1,000 \mathrm{r}$ will kill $100 \%$ of animals. Further a dose of more than $1,000 \mathrm{r}$ has not yet permitted an animal to tolerate a transplanted kidney for more than 49 days.

\section{Drugs}

Baker, Gordon, Huffer and Miller (1952) investigated the effects of nitrogen mustard, cortisone and splenectomy on renal homotransplants in dogs. The best result was 20 days function in a dog that had a combination of nitrogen mustard and cortisone in high doses. In I959 Schwartz and Dameshek produced a longlasting immunological tolerance of heterologous protein antigen in rabbits by treatment for 14 days 
with the purine analogue 6-mercaptopurine. Rabbits following an intravenous injection of human serum albumin were given $6 \mathrm{mg}$./kg. of 6-mercaptopurine daily, beginning on the day that the antigen was injected and continuing for two weeks. Control animals not given the 6-mercaptopurine reacted in the anticipated manner and produced a titre of antihuman albumin serum antibody. The drug-treated group showed no evidence of antibody formation. A month after the first injection of antigen, both groups of animals were given further injections of human serum albumin and also injection of bovine gamma globulin. The control animals developed typical secondary responses to the human serum albumin and primary responses to the bovine gamma globulin. The test group of animals still produced no antibodies to the human serum albumin but did react against the bovine gamma globulin. A month later further injections of human serum albumin and bovine gamma globulin produced secondary responses to bovine gamma globulin in both groups of animals, but still no antibodies were produced against the human serum albumin by the 6 -mercaptopurinetreated animals.

Thus with two weeks treatment with a high dosage of 6-mercaptopurine immediately following injection of antigen, Schwartz and Dameshek had produced a prolonged specific 'immunological tolerance' to the antigen in question and this tolerance persisted long after the drug had been stopped. The animals could still react against another antigen, indicating specificity of the tolerance.

Treatment of recipient animals with 6mercaptopourine was shown to prolong the functional survival of canine renal transplants (Calne, 1960, 196ra; Zukoski, Lee and Hume, 196r) and recently other thiopurines have been shown to be active, the most potent and consistent suppression of ther ejection process being produced by a combination of Actinomycin $\mathrm{C}$ and a黑 imidazolyl thiopurine, BW. 57-322 (Calne, 1961 Calne and Murray, 196r; Calne, Alexandre ang Murray, 1962). The thiopurines alone or 结 combination with other agents that have bee $\overrightarrow{\bar{f}}$ studied all lack consistency of action in non-toxict doses. Nevertheless nine bilaterally nephrectof mized dogs with renal transplants have survived more than three months with good renal function and three of these have survived six months.

Although the thiopurines probably impair rés sistance to infection both by their effects $\vec{D}$ immune competence and also by depression of the bone marrow, some degree of specificity probably determined by giving the drug during the inductive phase of the immune response to the antigen in question, namely the homologouss kidney. Pierce, Varco and Good (196I) have succeeded in producing a condition very like immunological tolerance in a dog treated witb 6-mercaptopurine, with a renal transplant from ato unrelated donor. This animal is now in goog health 18 months after transplantation, ten months after removal of its own two kidneys and nine months after stopping the 6-mercaptopurin包 Biopsy of the transplant revealed a mild homografe reaction, which has changed little during the kast. I6 months.

The above discussion reveals how fragmentary is our present knowledge of the basic phenomeng of the homograft rejection process and how in adequate are our methods of modifying this reaction. It is to be hoped that the ever increasing amount of research that is currently being directe to these problems will open up for exploitation the field of clinical renal transplantation.

Much of this paper has been taken from a monograp by the author entitled ' Renal Transplantation', shortl to be published by Edward Arnold Ltd. Material has also been taken from 'Prospects in Renal Transplanta tion', British Fournal of Clinical Practice, 16, 316, b. kind permission of the Editor.

\section{REFERENCES} Amos, D. B., Gorer, P.A., and Mikulska, Z. B. (1955): Analysis of Antigenic System in Mouse (H-2 System), Pro6
roy. Soc. B., 144, 369 .

Brit. भ. exp. Path., 35, 203.

, and WAKEFIELD, J. D. (1959): Growth of Mouse Ascites Tumour Cells in Diffusion Chambers: I. Study

Growth Rate of Cells and of the Rate of Entry of Antibody, F. nat. Cancer Inst., 21 (4), 657.

Anderson, D., Billingham, R. E., Lampkin, G. H., and Medawar, P. B. (I95I): The Use of Skin Grafting to Dis tinguish Between Monozygotic and Dizygotic Twins in Cattle, Heredity, 5, 379.

Attardi, G., Cohn, M., Horibata, K., and Lennox, E. S. (1959): Analysis of Antibody Synthesis at the Cellulato Level, Bact. Rev., 23, 213.

BAKER, R., and Gordon, R. (I955): Effect of Total Body Irradiation on Experimental Renal Transplantation, Surgery, 37, 820 .

Cortisone and Splenectomy, Arch. Surg. (Chicago), 65, 702.

Barnes, D. W. H., and Loutit, J. F. (1953): Protective Effects of Implants of Splenic Tissue, Proc. roy. Soc. Med.p $46,25 \mathrm{I}$.

, Ilbery, P. L. T., and Loutit, J. F. (1958): Avoidance of Secondary Disease in Radiation Chimeras, Natur (Lond.), I8r, 488 . 
Baronio, G. (1804): Degli Inneste Animali. Stamperia e fonderia del genio. Milan.

Batchelor, J. R., Boyse, E. A., and Gorer, P. A. (1960): Synergic Action Between Isoantibody and Immune Cells in Graft Rejection, Transplant. Bull., 26, 449.

BAUER, K. H. (1927): Homoiotransplantation von Epidermis bei eineiigen Zwillingen, Beitr. Klin. Chir., 141, 442.

Billingham, R. E., and Boswell, T. (1953): Studies on Problem of Corneal Homografts, Proc. roy. Soc. B, 141, 392. , and BRENT, L. (1957): A Simple Method for Inducing Tolerance of Skin Homografts in Mice, Transplant. Bull., 4, 67.

(I959): Quantitative Studies on Tissue Transplantation Immunity: IV. Induction of Tolerance in Newborn Mice and Studies on the Phenomenon of Runt Disease, Phil. Trans. B, 242, 439.

- - - and MEDawar, P. B. (1953): 'Actively Acquired Tolerance' of Foreign Cells, Nature (Lond.), 172, 603.

,--1 - (1956a): Antigenic Stimulus in Transplantation Immunity, Ibid., 178, 5 14.

(I956b): Quantitative Studies on Tissue Transplantation Immunity: III. Actively Acquired Tolerance, Phil. Trans. B, 239, 357.

, - , and SPARrow, E. M. (1954): Quantitative Studies on Tissue Transplantation Immunity: Survival Times of Skin Homografts Exchanged Between Members of Different Inbred Strains of Mice, Proc. roy. Soc B, 143, 43 .

, KroHn, P. L., and Medawar, P. B. (195 Ia): Effect of Cortisone on Survival of Skin Homografts in Rabbits, Brit. med. F., i, 1157 . Ibid., ii, r049.

Brent, L., and Medawar, P. B. (1961): Quantitative Studies on Tissue Transplantation Immunity: V. The Role of Antiserum in Enhancement and Desensitization, Proc. roy. Soc B, 155, 392.

, and Gowland, G. (1961): Cellular Dose and Age of Host in the Induction of Tolerance, Nature (Lond.), 192, 1265. , MedawAR, P. B., and Rusziewicz, M. (1961): Serological Methods in the Study of Transplantation Antigens, Brit. F. exp. Path., 42, 464 .

Burnet, F. M., and FENNER, F. (1949): ' The Production of Antibodies'. Melbourne: Macmillan.

(1959): 'The Clonal Selection Theory of Acquired Immunity'. London: Cambridge University Press.

CALNE, R. Y. (1960): The Rejection of Renal Homografts: Inhibition in Dogs by 6-mercaptopurine, Lancet, i, 417. (1961a): Observations on Renal Homotransplantation, Brit. F. Surg., 48, 384.

- (1961b): Inhibition of the Rejection of Renal Homografts in Dogs by Purine Analogues, Transplant. Bull., $28,65$. , and Murray, J. E. (196r): Inhibition of the Rejection of Renal Homografts in Dogs by Burroughs Wellcome 57-322, Surg. Forum, 12, 118.

Alexandre, G. P. J., and Murray, J. E. (1962): A Study of the Effects of Drugs in Prolonged Survival of Homologous Renal Transplants in Dogs, Ann. N.Y. Acad. Sci. In press.

Casey, A. E., Meyers, L., and Drysdale, G. R. (1948): Intratesticular versus Subcutaneous Transplantation of BrownPearce Tumour in New Zealand Whites, Proc. Soc. exp. Biol. (N.Y.), 69, 576.

Castermans, A., and Lejeune, G. (1962): Study of H-2 Antigens, Ann. N.Y. Acad. Sci. In press.

Coombs, R. R. A., Bedford, D., and Rouillard, L. M. (1956): A and B Blood Group Antigens on Human Epidermal Cells Demonstrated by Mixed Agglutination, Lancet, $\mathbf{i}, 46 \mathrm{r}$.

Davies, D. A. L. (1962): Chemical Nature of Mouse Histocompatibility Antigens, Nattire (Lond.), 193, 34.

DeMPSTER, W. J. (I953): Kidney Homotransplantation, Brit. F. Surg.. 40, 447.

Dresser, D. W. (1960): A Study of Immunological Mechanisms in Mice. Fh.D. Thesis, Lniversity of Edinburgh.

Dunsford, I., Bowley, C. C., Hutchison, A. M., ThCmrson, J. S., Sanger, R., and Race, R. R. (1953): A Human Blood Group Chimera, Brit. med. F., ii, 8I.

Eichwald, E. J., Silmser, C. R., and Wherler, N. (1957): The Genetics of Skin Grafting, Ann. N.Y. Acad. Sci., 64, 737 .

FagraEus, A. (1948): Antibody Production in Relation to Development of Plasma Cells: in vivo and in vitro Experiments Acta med. scand. Supp. 204, 130, 3.

Felton, L. D. (1949): Significance of Antigen in Animal Tissues, F. Immunol., 6r, 107.

Ferrebee, J. W., Lochte, H. L., Jaretski, A. L., Sahler, O. D., and Thomas, E. D. (1958): Successful Marrow Homograft in the Dog After Irradiation, Surgery, 43, 516.

Friedman, E. A., Retan, J. W., Marshall, D. C., Henry, L., and Merrill, J. P. (I961): Accelerated Skin Graft Rejection in Humans Pre-immunized with Homologous Peripheral Leukocytes, $\mathcal{F}$. clin. Invest., 40, 2162.

Gibson, T., and Medawar, P. B. (1943): Fate of Skin Homografts in Man, F. Anat., 77, 299.

, Curran, R. C., and Davis, W. B. (1957): The Survival of Living Homograft Cartilage in Man, Transplant. Bull., 4, ro5.

Good, R. A. (1961): Personal communication.

GoRer, P. A. (1937): Genetic and Antigenic Basis of Tumour Transplantation, F. Path. Bact., 44, 691.

(1938): Antigenic Basis of Tumour Transplantation, Ibid.. 47, $23 \mathrm{I}$.

- (1955): The Antibody Response to Skin Homografts in Mice, Ann. N.Y. Acad. Sci., 59 (3), 365. (1956): 'Advances in Cancer Research ', 4, 149. London and New York: Academic Press.

- and O'Gorman, P. (1956): The Cytotoxic Activity of Iso-antibodies in Mice, Transplant. Bull., 3, 142.

Graber, P., Courcon, J., Merrill, J. P., Ilberg, P. L. T., and Loutit, J. F. (1958): Immuno-electrophoretic Study on the Serum of Mice Irradiated by Lethal Doses of X-ray and Protected by Rat Bone Marrow, Ibid., 5, 58.

HaseK, M., HORT, J., and ChUTNA, J. (1962): Destruction of Tolerated Skin Heterografts by Means of Serum Antibodies, Ann. N.Y. Acad. Sci. In press.

Haskova, V., and Hrubesova, M. (1958): Part Played by Deoxyribonucle:c Acid in Transplantation Immunity, Nature (Lond.), 182, 61.

Herzenberg, L. A., and Herzenberg, L. A. (195I): Association of H-2 Antigens with the Cell Membrane Fraction of Mouse Liver, Proc. U.S. Nat. Acad. Sci., 47, 762.

Holman, E. (1924): Protein Sensitization in Iso-skin Grafting: Is the Latter of Practical Value?, Surg. Gynec. Obstet., 38, 100. 
Howard, J. G., and WoodrufF, M. F. (196r): Effect of the Graft versus Host Reaction on the Immunological Respon尺 siveness of the Mouse, Proc. roy. Soc. B, 154, 532.

Hume, D. M., Jackson, B. T., Zukoski, C., Lee, H. M., Kauffman, H. M., and Egdahl, R. H. (I960): The Homo $\$$ transplantation of Kidneys and of Fœtal Liver and Spleen After Total Body Irradiation, Ann. Surg., 152, 354. C

JACOBSEN, L. O. (1952): Evidence for Humoral Factor (or Factors) Concerned in Recovery from Radiation Injury: Review, Cancer Res., 12, 3 I 5. JENSEN, C. O. (1903): Experimentelle Untersuchungen uber Krebs bei Mausen, Centr. Bakteriol. Parasitenk, 34 122 .
28 and

Jensen, E., and Simonsen, M. (1962): Induced Tolerance After Parabiosis: Apparent Facilitation of Tolerance by a Simul을 taneous Graft versus Host Reaction, Ann. N.Y. Acad. Sci. In press.

Kaliss, N. (1958): Immunological Enhancement of Tumour Homografts in Mice: Review, Cancer Res., r8, 992.

Koller, P. C., and Doak, S. M. (1960): Serial Transfer of Donor Marrow in Radiation Mouse Chimeras, Int. radiat. Biol., 2, 1 .

Lanman, J. T. (1962): Insensitivity of the Placenta to Homograft Immunity, Ann. N.Y. Acad. Sci. In press.

LeXer, E. ( I 9 I I): Ueber freie Transplantationen, Arch. klin. Chir., 95, 827.

Lillie, F. R. (1916): The Theory of the Free-martin, Science, 43, 611 . Lorenz, E., Congdon, C. C., and Uphoff, D. (r952): Modification of Acute Irradiation Injury in Mice and Guinea-pigsu
by Bone Marrow Injections, Radiology, 58, 863.

Lower, R. R., Stofer, R. C., and Shumway, N. E. (196r): Homovital Transplantation of the Heart, Y. thorac. Surg 4I, I96.

Makela, O., and Nossal, G. J. V. (196r): Study of Antibody-producing Capacity of Single Cells by Bacterial Adherence्己. and Immobilization, $\mathcal{F}$. Immunol., 84 (4), 457.

Mann, L. T., Corson, J. M., and Dammin, G. J. (1960): Homotransplant Antigens: Preparation of Active Cellulait Fractions, Nature (Lond.), 187, 774.

Mannick, J. A., Lochte, H. L., Ashley, C. A., Thomas, E. D., and Ferrebee, J. W. (I959): A Functioning Kidneýr Homotransplant in the Dog, Surgery, 46, 821.

Mathe, G., Thomas, E. D., and Ferrebee, J. W. (1959): The Restoration of Marrow Function After Lethal Irradiation in Man: A Review, Transplant. Bull., 6, 407.

May, R. M. (1959): Bibliography of Brephoplastic Transplantation: Addendum No. I, Ibid., 6, 458.

MedawAR, P. B. (1944): Behaviour and Fate of Skin Autografts and Skin Homografts in Rabbits, $\mathscr{F}$. Anat., 78, 176.

(1945): Second Study of Behaviour and Fate of Skin Homografts in Rabbits, Ibid., 79, 157. cutaneous Tissue and to Anterior Chamber of Eye, Brit. F. exp. Path., 29, 58.

- (1956): Introductory Remarks, Proc. roy. Soc. B, 146, 922, 1 .

- (1957): Transplantation Immunity and Sub-cellular Particles, Ann. N.Y. Acad. Sci., 68, $2,255$.

— (1958): Part Played by Deoxyribonucleic Acid in Transplantation Immunity, Nature (Lond.), r82, 62.

- (1960): Ciba Foundation Symposium on Cellular Aspects of Immunity, p. 134. London: J. and A. Churchili

- - and Russell, P. S. (1958): Adrenal Homografts in Mice with Special Reference to Immunological Adrenalectorny Immunology, $\mathbf{1}, \mathbf{1}$.

Merrill, J. P., Murray, J. E., Harrison, J. H., Friedman, E. A., Dealy, J. B., and Dammin, G. J. (i96o) : Successfub̆ Homotransplantation of the Kidney Between Non-identical Twins, New Engl. F. Med., 262 , 1251.

Miller, J. F. A. P. (1961): Immunological Function of the Thymus, Lancet, ii, 748.

Mitchison, N. A. (r 953): Passive Transfer of Transplantation Immunity, Nature (Lond.), 171, 267.

- , and DubE, O. L. (1955): Studies on Immunological Response to Foreign Tumour Transplants in Mouse $\overrightarrow{\vec{D}}$ Relation Between Hemagglutinating Antibody and Graft Resistance in Normal Mouse and Mice PretreatecB with Tissue Preparations, 手. exp. Med., ro2, 179.

Moore, F. D., Wheeler, H. B., Demissianos, H. V., Smith, L. L., Balakura, O., Abel, K., Greenberg, J. B., ang Dammin, G. J. (г960): Experimental Whole-organ. Transplantation of the Liver and of the Spleen, Ann. Surg.: I52, 374 .

Murphy, J. B. (1926): Monograph of the Rockefeller Institute for Medical Research, No. 2 I.

Murray, J. E., Merrill, J. P., and Harrison, H. J. (1958): Kidney Transplantation Between Seven Pairs of Identicab Twins, Ann. Surg., 148, 343.

Nakic, Z. (1962): The Concept of Competitive Replacement, Ann. N.Y. Acad. Sci. In press.

Neptune, W. B., Weller, R., and Bailey, C. P. (1953): Experimental Lung Transplantation, F. thorac. Surg., 26, 275.

Nossal, G. J. V. (1959): Antibody Production by Single Cells: III. The Histology of Antibody Production, Brit. F. exp. Path., 40, 301.

Owen, R. D. (1945): Immunogenetic Consequence of Vascular Anastomoses Between Bovine Twins, Science, 102, 400

Pierce, J. C., VARCo, R. L., and Good, R. A. (196r): Prolonged Survival of a Renal Homograft in a Dog Treated witho 6-mercaptopurine, Surgery, 50, 186. Promelli, S., and Brooke, M. S. (r960): Erythrocytes as a Tool in Studies on Rabbit Radiation Chimeras and Secondar
Disease, Ann. N.Y. Acad. Sci., 87, 472.

, Behrendt, D. M., O'Connor, J. F., and Murray, J. E. (196r): Survival of Skin Homografts in Radiation Chimeras, Transplant. Bull., 27, 431 .

Porter, K. A. (1959): Use of Fœtal Hæmopoietic Tissue to Prevent Late Deaths in Rabbit Chimeras, Brit. F. exp Path., 40, 273.

(1960a): Immune Hemolysis: A Feature of Secondary Disease and Runt Disease in the Rabbit, Ann. N.Y. Acado Sci., 87, 391.

- and CALNE, R. Y. (1960): Origin of the Infiltrating Cells in Skin and Kidney Homografts, Transplant. Bull., 26, 458 0 Schinkel, P. G., and Ferguson, K. A. (1953): Skin Transplantation in the Fotal Lamb, Aust. F. exp. Biol., 6, 533.

Schwartz, R., and Dameshek, W. (1959): Drug-induced Immunological Tolerance, Nature (Lond.), r83, r682.

Simonsen, M. (1953): Biological Incompatibility in Kidney Transplantation in Dogs: Serological Investigations Acta path. microbiol. scand., 32, 36. 
Simonsen, M. (1957): The Impact on the Developing Embryo and New Born Animal of Adult Homologous Cells, Acta path. microbiol. scand., 40, 480 .

- Buemann, J., Gammiltoft, A., Jensen, F., and Jorgensen, K. (1953): Biological Incompatibility in Kidney Transplantation in Dogs: Experimental and Morphological Investigations, Ibid., 32, 1 .

SMith, R. T., and BRIDGES, R. A. (1958): Immunological Unresponsiveness in Rabbits Produced by Neonatal Injection of Defined Antigens, $\mathcal{F}$. exp. Med., 108, 227.

SNell, G. D. (1953a): 'Physiopathology of Cancer', p. 338. New York: Hoeber.

(1953 b): Genetics of Transplantation, $\mathcal{Y}$. nat. Cancer Inst., 14, $69 \mathrm{I}$.

- Winn, H. J., Stimpfling, J. H., and Parker, J. (1960): Depression by Antibody of the Immune Response to Homografts and its Role in Immunological Enhancement, $\mathcal{F} . \exp$. Med., 112, 293.

Steinmuller, D. (1962): Passive Transfer of Immunity to Skin Homografts in Rats, Ann. N.Y. Acad. Sci. In press.

Stetson, C. A., and Demopoulos, R. (1958): Reactions of Skin Homografts with Specific Immune Sera, Ibid., 73, 687.

Stormont, C., Weir, W. C., and LANe, L. L. (1953): Erythrocyte Mosaicism in a Pair of Sheep Twins, Science, I18, 695.

Teresaki, P. I., Bold, E. J., Cannon, J. A., and Longmire, W. P. (196r): Antibody Response to Homografts: VI. In vitro Cytotoxins Produced by Skin Homografts in Rabbits, Proc. Soc. exp. Biol. (N.Y.), 106, 133.

Thomas, E. D., Lochte, H. L., Cannon, J. H., Sahler, O. D., and Ferrebee, J. W. (1959): Supralethal Whole-body Irradiation and Isologous Marrow Transplantation in Man, $\mathcal{Y}$. clin. Invest., 38, 1709.

Trentin, J. J. (1956): Mortality and Skin Transplantability in X-irradiated Mice Receiving Isologous, Homologous or Heterologous Bone Marrow, Proc. Soc. exp. Biol. (N.Y.), $92,688$.

UPHOFF, D. E. (1958): Preclusion of Secondary Phase of Irradiation Syndrome by Inoculation of Fœtal Hematopoietic Tissue Following Lethal Total Body X-irradiation, f. nat. Cancer Inst., 20, 625.

Weaver, J. M., Algire, G. H., and Prehn, R. T. (1955): Growth of Cells in vivo in Diffusion Chambers: Role of Cells in Destruction of Homografts in Mice, Ibid., 15, 1737.

WoodRuFf, M. F., and SIMPSON, L. O. (1955): Induction of Tolerance to Skin Homografts in Rats by Injection of Cells from Prospective Donors Soon After Birth, Brit. F. exp. Path., 36; 494.

Zukoski, C. F., LeE, H. M., and Hume, D. M. (196I): The Effect of 6-mercaptopurine on Renal Homograft Survival in the Dog, Surg. Gynec. Obstet., I12, 707. 